\title{
Velfærdsstat og to-regimentelære ${ }^{1}$
}

\author{
professor, dr.phil. \& lic.oecon. \\ Jørn Henrik Petersen
}

\begin{abstract}
Primarily based on works by the British archbishop William Temple and the Norwegian bishop Eyvind Berggrav, the article reflects on the relation between the Lutheran doctrine of the two kingdoms and the development of the modern state in general and the welfare state in particular. At the end, the reception among Danish church people of the welfare state and Berggrav's views is presented.
\end{abstract}

Keywords: doctrine of the two kingdoms - welfare state - William Temple - Eyvind Berggrav - Alec Vidler.

\section{Artiklens tema}

Emnet er den anglikanske kirkes - primært biskop William Temples - og den norske biskop Eyvind Berggravs holdninger til det moderne samfund i almindelighed og velfærdsstaten i særdeleshed med særligt henblik på den lutherske to-regimentelære. Temples og Berggravs arbejder belyser forholdet mellem stat og kirke i den periode, hvor velfærdsstaten blev etableret, og der kastes derfor lys på den forskning, der ser en luthersk forkyndelse som "forklaring" på velfærdsstatens opståen. $^{2}$

1. En lettere bearbejdet version af et oplæg ved kursus for Herning nordre provsti på Teologisk Pædagogisk Center, Løgumkloster, den 18. november 2013.

2. Se Uffe Østergaard, "Lutheranismen, danskheden og velfærdsstaten”, 13 historier om den danske velferdsstat, red. Klaus Petersen (Odense: Syddansk Universitetsforlag 2003), 27-36; Uffe Østergaard, "Lutheranismen og den danske velfærdsstat", Velfardsstat og kirke, red. J.H. Schjørring og J.T. Bak (København: Anis 2005), 147184; Tim Knudsen, "Tilblivelsen af den universalistiske velfærdsstat", Den nordiske protestantisme og velfardsstaten, red. Tim Knudsen (Århus: Århus Universitetsforlag 2000), 20-64; Tim Knudsen, "De nordiske statskirker og velfærdsstaten", 13 historier om den danske velfardsstat, red. Klaus Petersen (Odense: Syddansk Universitetsforlag 2003), 37-47; Nils Gunder Hansen, Jørn Henrik Petersen \& Klaus Petersen (red.), I himlen således også på jorden? Danske kirkefolk om velfardsstaten og det moderne samfund (Odense: Syddansk Universitetsforlag 2010). Mens Østergaard lægger vægt på den lutherske forkyndelse som baggrund for velfærdsstaten, betoner Knudsen kirkens funktion som led i et offentligt, administrativt apparat. 


\title{
To-regimentelæren på kort form
}

Luthers skrift fra 1523 om den verdslige øvrighed ${ }^{3}$ og den augsburgske bekendelses artikel $28^{4}$ har været de væsentligste kilder til kirkens forståelse af forholdet til statsmagten.

Artikel 28 foreskriver, at den kirkelige og borgerlige magt ikke må sammenblandes. Den kirkelige lærer evangeliet og forvalter sakramenterne, og

\begin{abstract}
Den må ikke bryde ind på et fremmed myndighedsområde, ikke fordele verdslige riger, ikke afskaffe øvrigheders love, ikke ophæve lydigheden mod loven, ikke hindre retslige undersøgelser vedrørende nogen som helst borgerlige ordninger eller overenskomster, ikke foreskrive øvrighederne love om, hvordan statsformen skal indrettes (Nørgaard-Højen 2004, 165).
\end{abstract}

Luther så det politiske herredømme - den "verdslige øvrighed" - som en af Gud indsat institution, hvis lov og sværd udtrykte "Guds vilje og ordning i verden" (WA 11,247,22; Christensen 1980, 161).

Mens det åndelige styre "ved Helligånden skaber kristne og gode mennesker" (WA 11,251,16; Christensen 1980, 165), bremsede det verdslige styre "de ikke-kristne og onde mennesker, så de udadtil er nødt til at holde fred og forholde sig i ro meget imod deres egen vilje" (WA 11,251,17f; Christensen 1980, 165). "Det er Guds vilje at håndhæve det verdslige sværd og de verdslige love til straf for de onde og til værn for de gode" (WA 11,248,30f; Christensen 1980, 162). Magten skulle sikre mod "de ondes" overgreb, men ikke nødvendigvis have den enkeltes "velfærd" for øje. Der var således tale om en negativ frihed. Afskaffede man den verdslige lov og magt, ville man "løse de farlige rovdyrs lænker og kæder, så at de sønderflængede og sønderrev alle og enhver" (WA 11,251,26f; Christensen 1980, 165).

Derfor kunne ingen af de to styreformer undværes: "Den ene frembringer fromhed og retfærdighed, den anden skaber ydre fred og hindrer onde gerninger. Ingen af dem kan undværes her i verden" (WA 11,252,13f; Christensen, 166).

3. Martin Luther, Von weltlicher Uberkeytt, wie weyt man ihr gehorsam schuldig sey, D. Martin Luthers Werke. Kritische Gesamtausgabe (Weimar: Hermann Böhlaus Nachfolger 1900) = WA, 11,245-281. Oversættelserne efter Torben Christensen, Niels Nøjgaard m.f., Luthers Skrifter i Udvalg, bind IV, Evangelium og Samfundsliv (Forlaget Aros 1980), 158-210.

4. Peder Nørgaard-Højen, Den danske Folkekirkes Bekendelsesskrifter. Tekst og oversattelse (København: Anis 2004), 160-189. 
Heraf fulgte, at den kristne "med den største beredvillighed [underkaster sig] sværdets styre ... og gør alt, hvad han kan, for at gavne [stats]magten, så at den kan fungere og adlydes og respekteres, selv om han ikke personligt behøver eller trænger til noget af det" (WA 11,253,28-31; Christensen 1980, 168).

Det politiske herredømme skulle således opretholde orden og bekæmpe det destruktive.

Kobler man det med Luthers tanke om menneskets dobbelte natur ${ }^{5}$ - det åndelige indre og det legemlige ydre, er det kirkelige ansvar knyttet til menneskets åndelige, indre liv, mens staten bærer ansvar for det samfundsmæssige.

To-regimentelæren er ofte blevet tolket som en lære om statens suveræne magt, hvilket under nationalsocialismen af nogle blev set som legitimering af statsmagten. Lydighedspligten blev derfor kerne i de tyske teologiske stridigheder under det tredje rige. ${ }^{6}$ Ikke uden grund skriver Pierard $(1986,203)$ om den fejltagelse, som kristne i dette ulykkelige land gjorde sig skyldige i ved at bruge dette udsagn som legitimering af passivitet eller støtte af status quo.

\section{Den anglikanske kirke under og efter verdenskrigen}

Årene umiddelbart efter den 2. verdenskrig var i England præget af drømmen om "det nye Jerusalem". 7 Den liberale intelligentsia, kirkefolk med socialt perspektiv og moraliserende internationalister mente, at menneskelige svagheder kunne overvindes ved skabelsen af et "ideelt samfund". Denne elites Oxbridge-intellektuelle baggrund var farvet af en idealforestilling om menneskelighed rodfæstet i kristendom og klassicisme.

5. Martin Luther, Von der Freyheit eines Christen menschen, WA 7,20-38 (21). Se Inger Margrethe Kofod-Svendsen, Om et kristenmenneskes frihed, Martin Luther Skrifter i udvalg (København: Credo Forlag), 63-97, 69.

6. To-regimentelæren gav anledning til intens teologisk debat i Tyskland om den kristnes holdning til det nazistiske styre. Richard V. Pierard, "The lutheran twokingdoms doctrine and subservience to the state in modern Germany", Journal of the Evangelical Theological Society 29, 1986, 193-203, præsenterer hovedsynspunkter i denne diskussion.

7. Corell Barnett, The Audit of the War. The Illusion \& Reality of Britain as a great Nation (London: MacMillan 1986), titel på kapitel 1, 9-37. 


\section{William Temple}

Blandt kirkefolket gav ikke mindst den af bl.a. ærkebiskop William Temple arrangerede Malvern-konference i $1941^{8}$ og hans offentliggørelse af "Christianity and the Social Order" inspiration til en ny bevægelse indenfor Church of England. Den pegede i nogen grad frem mod en velfærdsstat. Temple anpriste således William Beveridges rapport om fremtidens sociale sikringssystem ${ }^{10} \mathrm{og}$ skrev, at det var "første gang nogen havde inkorporeret den hele kristne etiks ånd i et lovforslag".

Temple var til sin død i 1944 en af de mest indflydelsesrige skikkelser i den anglikanske kirke. "Christianity and the Social Order" blev, da den i 1942 udkom i en Penguin-udgave, solgt i mere end 140.000 eksemplarer. ${ }^{12}$ Han udviklede heri en række "sociale principper", der hvilede på hans populærversion af læren om arvesynden: "Enhver af os indtager sin plads i centrum for sin egen verden; men Jeg er ikke verdens centrum eller standardreferencen for en skelnen mellem godt og ondt; Det er Jeg ikke, men Gud er. Jeg sætter med andre ord fra begyndelsen mig selv på Guds plads. Det er min arvesynd” (Temple 1942, 36-38). Denne understregning af arvesynden betød to ting.

For det første at også den, der hørte Gudsriget til, var fristet til ikke at tage behørigt hensyn til sin næste. Det kunne kalde på en velfærdsstatslig intervention. For det andet at kirken til det yderste måtte være realistisk og ikke forfalde til utopisme (Temple 1942, 42). Derfor talte Temple ikke om idealer, men om principper. Især de to første er af betydning, når talen er om velfærdsstaten.

Det første princip lød, at "Hvis ethvert menneske er et Guds barn, som Gud elsker og for hvem Kristus døde, da har enhver en værdi, som er absolut og uafhængig af vedkommendes nytte for samfundet. Personen er primær, ikke samfundet: Staten eksisterer for borgeren, ikke borgeren for staten" (Temple 1942, 44f.).

8. MALVERN, The Life of the Church and the Order of Society, Being the Proceedings of the Archbishop of York's Conference, (London, Longmans, Green and Co., 1941).

9. William Temple, Christianity and Social Order, (London, a Penguin Special, 1942).

10. William Beveridge, Social Insurance and Allied Services. Report by Sir William Beveridge. Presented to Parliament by Command of his Majesty, (London HMSO CMND 6404, 1942).

11. Faktisk var Beveridges rapport på dette tidspunkt ikke udmøntet i et lovforslag, så Temples kommentar må vedrøre rapporten i sig selv. Alle oversættelser fra engelsk og senere fra norsk er mine.

12. E.R. Norman, Church and Society in England 1770-1970: A Historical Study, (Oxford, Oxford University Press, 1976), 367. 
Heri lå, at statens aktiviteter ikke var begrænset til alene at beskytte mod overgreb. Den havde også positive funktioner, herunder at imødegå den enkeltes fristelse til at vige af fra dydens smalle sti.

I det andet princip blev det fastslået, at "Mennesker er naturligt og ufravigeligt sociale (væsener), og i deres indbyrdes påvirkning 'danner' de hinanden. Det sker først og fremmest i familien og dernæst i alle de fællesskaber, der ligger mellem familien og staten. Enhver 'tæller for noget', og vi lever i indbyrdes afhængighed. Staten skal derfor fremme alle sådanne fællesskaber" (Temple 1942, 46-48).

Denne afhængighedstanke og betoningen af fællesskaber indgik også i Berggravs ræsonnementer.

Med langtidsarbejdsløshed som illustration viste Temple, ${ }^{13}$ hvordan kirken kunne anvende disse principper som grundlag for kritik af samfundet og foreslå ændringer, der kunne sikre en bedre overensstemmelse mellem virkelighed og principper. Det spejlede naturligvis, at man levede under en anden samfundsordning end på Luthers tid. Et demokratisk styre måtte betyde, at den enkelte var aktiv i begge regimenter. Tanken om lydighedspligt var overhovedet en tvivlsom affære i et demokratisk samfund.

På det mere detaljerede plan var det op til den enkelte kristne selv at danne sig sin opfattelse af, hvordan borgernes velfærd kunne fremmes, og hvad der var det fælles gode. ${ }^{14}$

Temple behandlede også i 1941 forholdet mellem stat og kirke. ${ }^{15}$ Statens opgave var at være kilde til og opretholder af lov, legalitet og legitimitet - en retsstat. Loven var ikke blot et middel til at begrænse friheden til at skade andre, men også til at sikre den enkeltes frihed til at leve som et godt menneske på trods af tilbøjeligheden til at handle på en anden måde. Han distancerede sig således fra Luthers vægtlægning på den negative frihed, og så det også som en opgave for "øvrigheden”, der nu måtte være identisk med 'det politiske system' eller staten, at tilvejebringe forudsætninger for, at den enkelte - også selv om Luther lod vedkommende tilhøre Gudsriget - kunne handle som "et godt menneske" på trods af sin fristelse til at handle anderledes.

Staten måtte ikke være 'magten' og sit eget formål, men skulle tjene som 'organ for fællesskabet'. Det var en tanke, han havde taget over

13. "Jeg kan ikke sige, hvad midlet er, men jeg kan sige, at et samfund, hvor arbejdsløshed er et vedvarende fænomen, er et sygt samfund, og hvis man ikke gør, hvad man kan for at finde midlet, er man skyldig over for Gud. I en række tilfælde, kan kirken gå videre og pege på træk i den sociale struktur, der fremmer social dårligdom, fordi de modsiger evangeliets principper" (Temple 1942, 45).

14. I et appendiks anførte Temple et "program", der korresponderede med kristne principper, men skrev samtidig, at der ikke kunne udarbejdes et program, som alle kristne med nødvendighed måtte endossere.

15. W. Temple, Citizen and Churchman, (London: MacMillan 1941). 
fra politologen Robert Morrison MacIver, ${ }^{16}$ og som han havde udmøntet allerede i 1928:17 "Staten er et organ for fællesskabet (community). Den har en afledt eksistens og en betinget autoritet. Den har derfor ikke i endelig forstand krav på loyalitet. Genstanden for den politiske loyalitet er det nationale fællesskab. Normalt er staten en nødvendighed i fællesskabet, og derfor er der normalt også tale om loyalitet over for staten; men staten kan være så dårligt ledet eller præget af en så stor afvigelse fra de sociale behov, at fællesskabet, hvis der ikke er midler til at reformere staten, må destruere den eksisterende stat, så den kan erstattes af en anden” (Temple 1928, 124).

Den enkeltes loyalitet (lydighedspligt) rettede sig således ikke mod staten (øvrigheden), men mod fællesskabet. Øvrigheden/staten havde ikke i Temples tænkning ubetinget autoritet, hvad den heller ikke, jf. nedenfor, havde hos Berggrav.

Det var således Temples opfattelse, at den kristne "var medlem af to samfund ... hvis funktioner blev styret af forskellige principper - eller snarere af forskellige relationer til det altafgørende slutmål: Guds herlighed i hans folks velfærd" (Temple 1941, 69). Det tegner en teologi, der har fællestræk med to-regimentelæren, men som alligevel adskiller sig i sin udviskning af forskellen mellem de to regimenter.

Kristendommen skabte "gode borgere" med sans for retfærd og lighed. De kunne derfor håndtere denne verdens problemer på en måde, som ikke-kristne ikke kunne (Temple 1941, 77-79). Derfor kunne kirken med autoritet udpege de mål, samfundet skulle søge virkeliggjort, hvis det skulle handle i overensstemmelse med Guds vilje - uden dog at være i stand til at foreslå specifikke veje til målenes realisering.

Hvis staten accepterede at bygge på kristne forudsætninger, bevægede den sig fra magtstat til velfærdsstat (Temple 1941, 82-83). ${ }^{18}$

16. Robert Morrison MacIver, Community, (London, MacMillan, 1917); Robert Morrison MacIver, The Modern State, (Oxford, Clarendon Press, 1926).

17. William Temple, Christianity and the State, (London: MacMillan 1928).

18. Temple anvendte ikke termen velfærdstat som udtryk for en stat med et omfattende socialt forsørgelsessystem men som en modsætning til "magtstaten". "Magtstaten har over tid givet efter for omstændighedernes pres; men det er imod magtstatens psykologi at lade sig ændre: Den vil kæmpe, før den lader velfærdsstaten indtage sin plads" (Temple 1928, 169-170). Tilsvarende talte Alec Vidler, "The Welfare State from a Christian Point of View, Theology 55 (1952), 441-448, om, at ændringen var en følge af økonomisk og politisk pres snarere end af social idealisme (Vidler 1952, 442).

Da Temple (1942) i et appendiks præsenterede konturerne af et egentligt socialt program anvendte han ikke termen velfærdsstat. I Parlamentets drøftelser af Beveridge-rapporten talte han om "de sociale ydelsers store institution" i stedet for brug af ordet "velfærdsstat", som andre anvendte, se HL Deb 25 February 1943, vol. 


\section{Lambeth-konferencen}

I 1948 samledes biskopper og fremtrædende kirkefolk i den Anglikanske kirke til den første Lambeth-konference efter krigen. ${ }^{19}$ I den generelle erklæring fra konferencen balancerede man mellem forskellige synspunkter på "den moderne stat" ${ }^{20}$ og understregede som Temple, at det var statens formål at tjene borgernes behov - ikke at gøre dem til sine undersåtter (Lambeth 1948, 19). Erklæringen skelnede ikke skarpt mellem "den moderne stat" og "velfærdsstaten".

Den kristne måtte, hed det i den femte resolution, vurdere et socialt system på dets virkning på den menneskelige personlighed. Der var derfor grund til at være på vagt over for tendenser til, at staten ville dominere (ud)dannelse og socialt arbejde - de personlighedsprægende aktiviteter. De havde hidtil været et ansvarsområde for kirken (Lambeth 1948, 20-21). Det "personlighedsprægende" hørte - uden at denne terminologi blev anvendt - til det åndelige regimente.

Om relationen mellem kirken og velfærdsstaten blev det i den 19de resolution fastslået (Lambeth 1948, part I, 32), at staten stod under Guds moralske lov og af Gud blev set som et middel til fremme af menneskelig velfærd. I en vis forstand var der kun et regime: Guds, som begge de to jordiske regimer måtte underkaste sig. ${ }^{21}$ De to regimer kunne således ikke være moralsk uafhængige af hinanden. I den grad staten handlede under respekt for Guds moralske lov, måtte kirken byde dens omsorg for borgerne velkommen og appellere til sine medlemmer om at acceptere deres individuelle politiske ansvar og at samarbejde med staten og dens repræsentanter.

I et særligt afsnit (Lambeth 1948, part II) om forholdet mellem kirken og den moderne stat blev der advaret mod "magtstaten", den omnipotente stat eller velfærdsstaten, "som den undertiden kaldes", fordi den tenderede at ændre kirkens og statens respektive ansvarsområder. Det måtte derfor være en kirkelig opgave at vogte den personlige frihed, at være modvægt til "statens naturlige tendens mod totalitarisme" og at beskytte "ånden bag de frivillige sociale ydelser"

126 cc 307-355, især 315-320. Hans statskritik var derfor først og fremmest vendt mod "magtstaten".

19. Lambeth Conference 1948, Encyclical Letter from the Bishops together with the Resolutions and Reports, (London: SPCK, 1948). Lambeth-konferencerne afholdes hvert tiende år for den anglikanske kirke arrangeret af ærkebiskoppen af Canterbury. De på disse konferencer vedtagne resolutioner har ingen bindende virkning, men har gennem årene øvet betydelig indflydelse på tænkningen i de kirker, der er forenet i den anglikanske kirke.

20. Flere resolutioner bar den generelle overskrift: "Kirken og den moderne stat".

21. Historisk har der oftest været tale om en klar skelnen mellem de to regimenter, men det var nu nok snarere Luthers tanke, at Gud udøvede sin magt i begge regimenter. 
(diakonien) (Lambeth 1948, part II, 17-18). Det frivillige og frie arbejde skulle på den ene side være "drivkraft" og pioner, mens det på den anden side skulle kunne samarbejde med offentlige institutioner.

\section{Andre anglikanske røster}

Allerede forud for Lambeth-konferencen havde Londons biskop, J.W.C. Wand, vurderet, at velfærdsstaten var en videre udvikling af kirkens humanitære arbejde, ${ }^{22}$ og i 1952 mente den indflydelsesrige anglikaner Roger Lloyd at kunne "retfærdiggøre" velfærdsstaten i eksplicitte kristne termer, fordi det både af Bibelen og den kristne teologi fulgte, at det var Guds ønske for det enkelte menneske, at det kunne leve med en rimelig grad af materiel sikkerhed. ${ }^{23}$ Han så m.a.o. ikke øvrighedens opgave alene som den at beskytte den enkelte mod overgreb. Øvrigheden skulle også varetage hensynet til den enkeltes materielle vilkår.

Ærkebiskoppen af York, C. Garbett, mente, at velfærdsstaten spejlede det kristne syn, der lader os "bære hinandens byrder", men han advarede samtidig imod, at staten alene fokuserede på menneskets materielle behov. Det ville svække den personlige ansvarlighed - en reservation der deltes af mange britiske kirkefolk. ${ }^{24}$ Omvendt betød det, hvis staten gik videre, at den tillagde sig en ansvarlighed, der rakte ind i "det åndelige".

Mens den konservative opinion var skeptisk over for øget statslig aktivitet, blev velfærdsstaten således modtaget forholdsvis positivt $\mathrm{i}$ kirkelige kredse i England.

\section{Alec Vidler}

Ikke mindst teologen og religionshistorikeren Alec Vidler overvejede forholdet mellem velfærdsstaten og kristendommen. ${ }^{25}$ Ingen kunne, understregede han, hævde velfærdsstaten som en gyldig norm eller standard for statens indretning efter Guds lov (Vidler 1952, 443). Gud havde ikke defineret en bestemt statstype som den rette; men det kunne meget vel være tilfældet, at velfærdsstaten under de givne historiske vilkår var det bedste middel til at imødekomme alle borgeres menneskelige behov. Den kunne være vejen ad hvilken, mennesket som del af et nationalt samfund kunne hjælpes til "at elske sin næste", og hvorved man bedst kunne tilnærme sig centrale dele af et fælles

22. J.W.C. Wand, God and Goodness, (London: Eyre \& Spottiswoode, 1947), 56.

23. Roger Lloyd, The Church and the Artisan today, (London: Longmans Green, 1952), 32 .

24. C. Garbett, In an Age of Revolution, (London: Pelican Books 1952), 151.

25. Alec R. Vidler, "The Welfare State: A Christian View”, Theology 55 (1952), 441-448. 
liv i Kristus, idet velfærdsstatens grundpåstand om "retfærdighed" kunne ses som "kærlighed på afstand" (Vidler 1952, 445).

Vel var, understregede Vidler, en stat nødvendig for at sikre den indre orden og forsvaret mod ydre fjender, men loven og profeterne bevidnede, at et nationalt samfund måtte indrette det fælles liv, så de magtfulde blev begrænset i deres udfoldelser, og så alle samfundsmedlemmers behov - også de fremmedes, der befandt sig inden for territoriets porte - blev varetaget (Vidler 1952, 443-444).

Faktisk så han velfærdsstaten som vejen, fordi mennesker i moderne industrialiserede samfund var i en stadig større indbyrdes fysisk afhængighed, hvilket rejste behov for at udvikle en tilsvarende moralsk interdependens, så den enkeltes magt over andre blev brugt til disse andres fordel. Vaner og traditioner måtte suppleres med institutioner, der ville gøre det muligt - om nødvendigt med tvang - for mennesker at drage omsorg for hinanden (Vidler 1952, 445). Det knyttede klart staten og dens lovgivning til kærlighedsbuddet.

Vidlers positive holdning til trods var han dog bekymret for velfærdsstatens virkninger på det frivillige arbejde, på familiens funktion og på den personlige frihed og ansvarlighed (Vidler 1952, 447).

Mens der således i velfærdsstatens unge år blev peget på nødvendigheden af en balance mellem flere forskellige dimensioner i det menneskelige liv, var den efterfølgende periode mere præget af en voksende bekymring for, at en sekulær humanisme skulle blive dominerende. Det var en frygt anglikanerne delte med Eyvind Berggrav.

\section{Magten og modernitetens dæmoni}

Den norske biskop Eivind Berggrav så i den nyere kultur- og åndshistorie to udviklingslinjer, der i det 20. århundrede flød sammen. ${ }^{26}$

Den ene kaldte han suverænitetslinjen. Den spejlede statens forsøg på at være sig selv (nok), idet den henviste alle "uvedkommende" til at forblive indenfor deres "egne områder". Staten nægtede, at det hellige havde gyldighed på dens eget område, selv om det gjorde sig gældende på andre (Berggrav 1945, 45).

Den anden var sekulariseringslinjen. Den udtrykte, at det hellige blev stadigt nedtonet både som statsforpligtende og som kulturbærende (Berggrav 1945, 45).

26. Eyvind Berggrav, Staten og mennesket. Oppgjør och Framblikk, (Oslo: Land og Kirke, 1945). 
Suverænitetslinjen løb ud i adskillelsen af staten fra det helliges sfære, mens sekulariseringslinjen endte $i$ en fornægtelse af alt andet end det materielt virkelige.

Når de to linjer føø sammen, rev strømmen dem med sig, der ellers skulle lede den. Statens ideologi slog over i magtautomatiske funktioner, der skulle tilpasse menneskene. Staten ville ikke menneskeliggøres, men menneskene skulle statsliggøres (Berggrav, 1945, 36) - netop det Temple advarede imod. Det var, hvad Berggrav kaldte, det dæmoniske (1945, 54).

Den dæmoniske stat var en suveræn magt, som var uafhængig af mennesker, af Gud, af moral og af samvittighed. Derfor var retten blevet til "magt-matematik", og "retsfølelsen" var reduceret til en romantisk drøm. Hvor Temple frygtede magtstaten, var Berggravs frygt den dæmoniske stat.

\section{Eivind Berggrav}

Eivind Berggrav spillede en stor rolle i den norske og den europæiske velfærdsstatsdiskussion og var særdeles kendt i danske kirkekredse. Således gengav Presteforeningens Blad Berggravs meget omtalte foredrag ved Det lutherske Verdensforbunds møde i Hannover i 1952, hvor han eksplicit forholdt sig til velfærdsstaten. ${ }^{27}$

Berggrav var i første del af sit indlæg optaget af kirkens lydighedspligt i forhold til staten - overhovedet kirkens forhold til den moderne stat, ${ }^{28}$ mens han i den anden del rettede fokus mod velfærdsstaten i dens nordiske udformning.

\section{Berggrav om to-regimentelaren}

Den lutherske lære forudsatte, mente Berggrav, at staten var en retsstat, ${ }^{29}$ og at sværdet derfor var rettens redskab (Berggrav 1952,

27. Eyvind Berggrav, "Stat og kirke i dag etter luthersk syn". Foredrag på det lutherske verdensforbunds møte i Hannover, Kirke og Kultur 57 (1952), 449-467. Også trykt i Presteforeningens Blad 42 (1952), nr. 34, 35 og 37.

28. Det var en problematik Berggrav i forbindelse med den norske kirkekamp havde været stærkt optaget af. Netop den norske kirkes forhold til nazismen spillede en stor rolle i hans ræsonnementer. Kirken havde, sagde han, alt for ofte været støtte for den til enhver tid herskende magt; men det historisk overleverede i lutherdommen kunne ikke være bindende for en nutid, men alene virke korrigerende og inspirerende (Berggrav 1952, 450).

29. "Uden ret ingen ret øvrighed" (Berggrav 1952, 451). I den fjerde af tolv teser om forholdet mellem stat og kirke efter luthersk syn, (Berggrav 1952, 463-467), understregede han, at kristne - uanset om statens repræsentanter var gudløse - skulle 
451). ${ }^{30}$ En øvrighed, der byggede på tyranni og lovløshed, kunne ikke anerkendes. Der var altså ikke et krav om lydighed under enhver omstændighed og over for enhver øvrighed. ${ }^{31}$ Det var retten og ikke magten, der begrundede lydighedspligten. Retten stod over staten (Berggrav, 1952, 452). Derfor var det en kristen og kirkelig opgave vedvarende at udsætte øvrigheden for en lakmusprøve, som holdt dens gerninger op mod Guds ord (Berggrav, 1952, 451). Det var en tanke, som ikke mindst var udmøntet i William Temples skrifter over perioden fra 1928 til $1944 . .^{32}$ Det er en retsstatsopfattelse, der

adlyde øvrigheden i den udstrækning, "den var de jure og ordens og retfærds tjener”, hvilket, sagde den femte tese, ud fra ændrede tidsforhold og nye statstendenser betød, at når den totalitære stat til forskel fra lovstaten blev politistat med vilkårligt tyranni, var den en Gudsfjende, der måtte mødes af kristen modstand. Der kunne kun, lød det i tese 7 , samarbejdes med staten, hvis den var en retsstat.

30. Dette synspunkt er beslægtet med Temples tidlige anvendelse af begrebet velfærdsstat, se William Temple, Christianity and the State, (London: MacMillan 1928), hvor begrebet velfærdsstat fremtræder som en modsætning til magtstaten. Om Temples argumenter og hans plads i historien om velfærdsstatens udvikling, se Klaus Petersen \& Jørn Henrik Petersen, "Confusion and divergence: Origins and meanings of the term 'welfare state' in Germany and Britain", Journal of European Social Policy 23 (2013), 37-51.

31. Når kusken er gal (Berggrav 1945, 219-232) var et foredrag, Berggrav i foråret 1941 holdt på forskellige møder for norske præster. Det var et opgør med den traditionelle udlægning af to-regimentelæren. Foredraget blev spredt illegalt blandt norske præster. Hans opfattelse skal ses i tæt sammenhæng med hans bidrag til dokumentet "Kirkens grunn", der blev oplæst fra prædikestolene i landets kirker 1. påskedag 1942 (http://www.fagsider.org/kirkehistorie/dokument/1942_kirkens_ grunn.htm; besøgt 09.12.14). Dokumentet havde til formål at præcisere den norske kirkes forhold til NS-regeringen. For en diskussion af "Kirkens Grunn" henvises til Torleiv Austad, Kirkens Grunn (Oslo: Luther Forlag 1974).

Nok tog det afsæt i to-regimentelæren, men afsnit $\mathrm{V}$ om forholdet til øvrigheden blev afsluttet med en markant erklæring: "På grundlag af skrift og bekendelse må kirken derfor tage stilling til de tilfælde, hvor der bliver rejst totalitære krav om også at herske over samvittighederne, og når man vil nægte retten til at prøve alt på Guds ords grund efter den kristne overbevisning. Derfor er det for kirken i strid med Guds befaling, når det hævdes, at den verdslige magt skal have "den højeste øvrighed og den største ret over hver enkelt borger” på en sådan måde, at samvittighederne ikke har adgang til at bedømme lydighedspligten mod den verdslige øvrighed på Guds ord”. Ifølge "Kirkens grunn” var der forskel på “øvrighed” og "ret øvrighed". Var øvrigheden til rædsel for sjælene, når de fulgte Guds vej, var den ikke øvrighed efter Guds vilje, og da måtte kirken lade øvrigheden høre sandhedens ord. Øvede staten vold mod retten, var det kirkens ansvar at tale den imod. I sin 1952tale i Hannover satte Berggrav i virkeligheden velfærdsstaten på samme plads som NS-staten - et demokratisk vedtaget statsstyre på samme plads som en totalitær stat!

32. Begrebet retsstat spejler en ideologi, der vil afgrænse statens magtsfære, sikre forudsigelighed i de statslige handlinger og skabe plads også for private initiativer og handlinger; men det er vigtigt at understrege, at retten i Berggravs forståelse var hellig og funderet i Gud. Derfor var retten hævet over menneske og samfund - en 
åbnede kirken muligheder for at handle i protest mod staten, og som i virkeligheden pålagde kirken et sådant ansvar, hvis staten øvede vold mod retten.

En sekulariseret stat kunne ikke påkalde sig to-regimentelæren, fordi den fordrede anerkendelse af Gud, som dén alle, også regeringerne, stod til regnskab over for. To-regimentelæren betød ikke, betonede Berggrav, at det jordiske liv havde to regimenter, men at Gud styrede verden på to forskellige måder. ${ }^{33}$

Derfor havde staten ansvar for at fremme ret og retfærdighed. Hvis staten krænkede retten og stillede totalitære krav om at bestemme kirkelige forhold, og hvis staten krænkede individernes frihed til at følge deres samvittighed i religiøse og etiske spørgsmål, havde den påtaget sig en illegitim rolle.

Det betød også, at kirken måtte kritisere den stat, som ville herske over sine borgere i spørgsmål om tro og livssyn - livssynsstaten, jf. nedenfor.

Den kristne havde hjemme i begge regimenter og bar både et statsligt og et kirkeligt ansvar. Det indebar såvel et ansvar for at fremme fællesskabet i et samfund båret af ret og retfærdighed som et ansvar for at værne om kirkens ret til at være kirke - uden ydre ideologisk og politisk indblanding.

\section{Berggrav og velfardsstaten}

Berggrav (1952) benyttede "velfærdsstaten" som alment politisk begreb, der sammenfattede en række for efterkrigstiden karakteristiske udviklingstræk. ${ }^{34}$

Velfærdsstaten var en sekulær stat, der ville indtage forsynets plads, og som ville erstatte nazisternes "livsanskuelse" med opdragelse til "demokratisk sindelag" (Berggrav 1952, 457). Det betød i Berggravs optik, at det totalitære genfandtes i det demokratiske - en sekulariseret livssynsstat, som totaliserede demokratiet. Det problematiske ved velfærdsstaten var, at den tillagde sig selv en overordnet rolle og trængte ind på alle livets områder - med risiko for at kirken fortræng-

version af en kristen naturretstænkning - ikke en positivistisk retsforståelse. Det er den "guddommelige" og ikke den positive ret, der var i centrum. Staten var bundet af det hellige, uden selv at være hellig. Den kunne derfor ikke være selvstændig moralsk aktør. Berggrav refererede ikke hverken i 1945 eller i 1952 til Temple. Begge arbejdede i det store og hele uden referencer; men der er et klart slægtskab mellem Berggravs og Temples synspunkter.

33. Berggrav (1952), tese 2, 464: "Der er kun en øvrighed - det er Gud, og der er bare en lydighed, det er lydigheden mod Gud - hvem det så end i øjeblikket måtte være, der repræsenterer hans vilje."

34. Om Berggravs velfærdsstatskritik se også Aud V. Tønnesen, "Velferdsstaten og den lutherske toregimentlæren”, NTT 112 (2011), 196-212. 
tes fra samfundslivet. Velfærdsstaten afviste "enhver anerkendelse af Gud som livets Herre" og så sig "berettiget til at gribe ind på alle menneskelige områder" (Berggrav 1952, 457).

Sekulariseringen brød med to-regimentelærens forudsætning om, at Gud var ansvarlig for begge regimenter. Om end statsmagten hvilede på et folkeligt mandat, var der ikke sat en grænse for dens virkeområde.

\section{Berggravs konkrete kritik}

I sin argumentation i $1956^{35}$ var Berggrav tæt på den fremherskende kritik fra borgerlige, liberale positioner, ${ }^{36}$ idet han dog lagde afstand til deres individualistiske perspektiv gennem sin betoning af fællesskabet og livsgrupperne (Berggrav 1956, 194). Velfærdsstaten fratog, sagde han, den enkelte ikke blot det tyngende, men også det forpligtende ansvar. Den dovne og den flittige, ordensmanden og sjusken fik samme tryghed (Berggrav 1956, 195) - en kritik der pegede bagud til det 19. århundredes skel mellem værdigt og ikke-værdigt trængende.

Risiko og spænding blev fjernet fra tilværelsen, og det ville på det længere sigt skabe et slapt samfund (Berggrav 1956, 195) - demoralisering. Når man var betrygget, mistede man initiativ og lyst til indsats og koncentrerede sig i stedet om at bjerge sig en ekstra fordel. Konsekvensen var et samfund, der byggede på mistænksomhed og udviklede en stadigt skærpet kontrol. Det gjorde samfundet upersonligt uden kontakt og varme. Så var det ikke længere et samfund af mennesker, men en løsagtig masse uden personlig glæde ved hjælp, fordi den blev ydet som en ret, hvor den enkelte bare krævede sit (Berggrav 1956, 195-96) - disintegration.

Det, som evangeliet ville give den fattige eller syge som gave eller nåde, ville velfærdsstaten tildele som en ret (Berggrav 1952, 458). Det var for Berggrav et problem, fordi den frivillige given og modtagelse af gaver knyttede bånd mellem klasserne og derved bidrog til at fastholde et fællesskab. ${ }^{37}$ Det placerede ansvaret hos den enkelte; men hvis gaven blev erstattet med retten, var det en trussel mod diakonien, fordi man ville bygge på autorisation på grundlag af betingelser, som staten formulerede. Risikoen var da, at staten ville tillægge sig

35. Eyvind Berggrav, "Redaksjonelle noter", Kirke og Kultur 61 (1956), 193-96 (195). Delvis optrykt som "Ansvaret i velfærdsstaten", Vestkysten 1956 den 10. august; se også "Magasin Staten”, Jydske Tidende den 20. juni 1956.

36. Man skal da også se Berggravs mere konkrete velfærdsstatskritik som udslag af hans placering i en liberal politisk tradition. Han spillede efter sin afgang som biskop en rolle i det fallerede politiske projekt, der ville samle Venstre, Senterpartiet og Kristeligt Folkeparti i Det norske Folkeparti.

37. Berggrav $(1945,144)$ så forpligtetheden i den foragtede "private godgørenhed" som kernen i den solidaritet, der var nerven i folkets socialfølelse. 
rollen som al-fader eller omnipotent stat. En altomfattende velfærd førte til en alt-kontrollerende og alt tvingende magt. Velfærdsstaten blev da en "indgrebsstat" - en krydsning mellem totalitær og demokratisk stat (Berggrav 1956, 193-94).

Herved blev staten fristet til at indtage Guds plads, så Gud og troen på ham blev overflødig. Det var således Berggravs frygt, at den sekulariserede velfærdsstat ville fortrænge kristendommen og sætte staten i Guds sted. Berggravs velfærdsstatsskepsis spejlede hans opfattelse af velfærdsstaten som et sekulært og materialistisk statsprojekt.

Tanken om næstekærlighed var politisk forpligtende "til at gå ind for alt, der politisk kan bidrage til at gøre livet bedre og rigere for mine medmennesker", som han skrev til en dansk journalist; men den kunne ikke realiseres i projekter, der ville tage alt ansvar fra individerne. ${ }^{38}$ Næstekærligheden trivedes bedst i livsgrupperne.

\section{Berggravs livsgrupper}

Bag Berggravs kritik lå den grundopfattelse, at staten og kirken havde forskellige opgaver (Berggrav 1945, 139-147). Derfor måtte staten ikke blive alt dirigerende og kontrollerende. Han advarede (Berggrav 1956) mod "indgrebsstaten", der ville dirigere det personlige liv.

Staten skulle alene gennem sin lovgivning lægge forholdene til rette, så "livsgrupperne" kunne udfolde sig. Livsgrupperne var bærere af samfundets sociale og kulturelle behov, sociale fællesskaber med familien som kerneenhed. De var kendetegnet ved personlig kontakt, nærhed og omsorg og var i den forstand modstykket til interessegrupperne. Det var i livsgrupperne den moralske ansvarlighed og omsorg var forankret. Staten kunne ikke være personlig og nær og derfor ej heller tegne moral og fællesskab. Statens magt måtte være begrænset af livsgruppernes virksomhed. Dens opgave var alene at sikre retten, mens den åndelige og moralske forkyndelse samt omsorgen var et kirkeligt ansvar. Kirken blev således tildelt en samfundsopdragende rolle. Næstekærligheden blev perverteret, når den blev institutionaliseret i velfærdsstaten.

I velfærdsstaten og overhovedet i den intervenerende stat så Berggrav en stat med en overordnet moralsk opdragende opgave, der brød med retsstatens grundlæggende principper og førte staten ind i livsgruppernes sfære, hvor den ikke havde noget at gøre. Det var livsgrupperne, der var kerne i fællesskabet - ikke velfærdsstaten.

38. Citeret fra Aud V. Tønnesen, “... et trygt og godt hjem for alle”? Kirkelederes kritikk av velferdsstaten etter 1945 (Trondheim: Tapir Akademisk Forlag 2000), 295, jf. også slutordene i den tolvte tese (Berggrav 1952, tese 12, 467): "Kristi ord om omsorgen for næsten lægger et dybt ansvar og en daglig forpligtelse på hver kristen og på hver kirke, både overfor staten og overfor folkenes og hjemmenes liv". 
Tanken var beslægtet med mellemkrigstidens anglikanske socialteologi, der også hvilede på en skelnen mellem stat og fællesskab. For Temple var velfærdsstaten, som vi så, en stat, der virkede som "an organ of community". Helt tilsvarende talte Berggrav $(1945,13)$ om staten som "organet for alles samvirke". For både Temple og Berggrav lå det kit, der kunne sikre fællesskab og sammenhængskraft i de mindre livsgrupper. ${ }^{39}$

Velfærdsstaten var for Berggrav en sekulær livssynsstat, der ville fortrænge kristendommen og sætte sig i Guds sted: "Denne stat ønsker ... at være en slags alfader. Den moderne velfærdsstat vil være omnipotent. Om direkte religiøs tilbedelse bliver der ikke tale. Men det vil være sådan, at staten skal være nok. Udover staten behøver mennesker ikke noget forsyn. Den moderne stat, som i dag er i fuld udvikling, fristes for så vidt til at indtage Guds plads, så Gud og troen på ham bliver overflødig" (Berggrav 1952, 460).

Den kristne skulle være samfundets 'surdej' og 'salt' og virke for, hvad staten skulle være: retsstat - ikke omsorgsstat, ikke opdragelsesstat (Berggrav 1952, 462).

Mens anglikanerne havde et forholdsvis positivt forhold til velfærdsstaten, var Berggrav skeptiker. Anglikanerne gik kun indirekte ind i diskussionen om to-regimentelæren, mens Berggrav betonede, at den næppe kunne opretholdes, fordi "den nye stat" greb så dybt ind i det åndelige, at der ikke længere ville være nogen plads for kirken, Berggrav $(1952,457)$.

\section{Danske kirkefolks modtagelse af velfærdsstaten}

Stiftsprovsten i Odense K.L. Aastrup ${ }^{40}$ lå tæt på Berggravs synspunkter. Mens forsorgsarbejdet tidligere hvilede på barmhjertighed betød velfærdsstaten, at giverens gavmildhed blev erstattet af modtagerens krav på samfundet. "Rente erstattede understøttelse". Gaven og nåden var erstattet af retten - ganske som hos Berggrav. "Vi kan ikke nå frem til et Samfund, hvor vi kan nøjes med at modtage og yde

39. I december 1940 var Berggrav i London i forbindelse med "den nordiske fredsplan”. Han mødte her Temple, som han i forvejen kendte fra det økumeniske arbejde i 30'erne, se Gunnar Heiene, Eivind Berggrav. En biografi (Oslo, Universitetsforlaget 1992), 284f. Temple var på det tidspunkt ved at afslutte et par af sine sidste arbejder. Der er træk i Berggravs arbejder, der antyder, at han har haft kendskab til Temples tænkning.

40. K.L. Aastrup, "Demokrati og forsorgsvæsen”, Jyllands-Posten den 15. september 1951. 
Retfærdighed og ikke har Brug for Barmhjertighed, og skal heller ikke ønske det. Det vilde blive et umenneskeligt Samfund”.

I en artikel i menighedsbladet for Helligåndskirken i København stillede lutherspecialisten, sognepræst dr.theol. Svend Lerfeldt ${ }^{41}$ spørgsmålet, om ikke velfærdsstaten "med sin tro på sig selv sætter sig på Guds trone".

Teologen, seminarieforstander Paul Holt ${ }^{42}$ så "den absolutte velfærdsstat" (Holt 1955, 3) som en parallel til de totalitære samfund. I den absolutte velfærdsstat var der intet over og intet ved siden af staten, der blev "Gud", politikken, der blev Religion, og statens ideologi, der blev "Frelseslære" (Holt 1955, 5). Selv en mindre udviklet velfærdsstat var et problem, fordi medansvarligheden i samfundet blev "afpersonificeret" (Holt 1955, 5). En stat, der satte sig selv i Guds sted, måtte afvises.

Johs. Horstmann udmøntede Tidehvervs synspunkt på velfærdsstaten i tre artikler. Det kunne ikke være kirkens opgave at identificere buddet om at elske næsten med arbejdet for medmenneskets timelige lykke. ${ }^{43}$ Når øvrigheden ville ordne samfundets liv, da satte den sig i Guds sted. Den blev dæmonisk, fordi den guddommeliggjorde menneskelige værdier (Horstmann 1961a, 4). Det var kirkens sociale opgave at sikre, at der ikke blev drevet afguderi med ansvaret for næsten (Horstmann 1961b, 23).

Velfærdsstaten var et religiøst fænomen, fordi troen på velfærdsstaten blev set som menneskets absolutte mål. ${ }^{44}$ Når staten overtog ansvaret for næsten, ville den heri se en religiøs og kristelig retfærdiggørelse af sit mål; men just det måtte kirken sige fra overfor (Horstmann 1961c, 65-66).

Flere ytrede bekymring for kirkens diakonale arbejde, der ville blive hæmmet af statens virksomhed, hvilket ville fremme en i forvejen fremadskridende sekularisering, og det ville betyde, at velfærdsstaten også ville herske over menneskers samvittighed. ${ }^{45}$ Derfor kunne diakoni ikke erstattes af social - human forsorg. Den manglede det ord,

41. Her refereret efter en ledende artikel i Sønderjyden, Haderslev, den 2. februar 1956.

42. Paul Holt. "Velfærdsstaten - en historisk analyse og en kristen kritik", Frihed og Fallesskab 17 (1955), 3-6. Se også "Hvorfor er mennesker ikke lykkelige i velfærdsstaten”, Kristeligt Dagblad den 15. december 1955.

43. Johs. Horstmann, "Kirkens politiske og sociale opgave I", Tidehverv 35, 1-2 (1961a), 1-8, 2; se også Johs. Horstmann, "Kirkens politiske og sociale opgave II", Tidehverv 35, 3 (1961b), 22-27.

44. Johs. Horstmann, "Velfærdsstatskristendom", Tidehverv 35, 8-9 (1961c), 6175,61 .

45. Se fx Jens J. Jensen, "Kirkens plads i velfærdsstaten”, Fyns Venstreblad den 17. september 1952. Kronikken er en kort parafrase over Berggrav 1952. 
"der vederkvæger sjælen”. Den "vidner ikke om Guds godhed, men om sin egen”. ${ }^{46}$

Der var dog også mange med praktisk virke i det diakonale arbejde, som så muligheden for at samspil mellem det kirkeligt funderede diakonale arbejde og det offentliges indsats. Velfærdsstaten ville ikke blive en sovepude for kirken, fordi den ved sin uundgåelige ophobning, sin kasernering af forsorgen i anstalter og institutioner og 'hjem' o.l., havde skabt et næsten umætteligt behov for pleje og omsorg, forståelse og personlig hjælp. ${ }^{47}$ "Diakonien skulle være den pigkæp, der bestandig driver på staten, så den yder sit bedste og ikke falder i søvn i egen selvglæde, fordi ingen har det myndige ord, der kan udfordre" ${ }^{48}$ Netop på grund af velfærdsstatens sikring af det materielle var det muligt at "mobilisere vore egne varmekilder som modtræk, lune op, live op, hygge og trygge om hinanden" (Krabbe 1959, 124) - og om dem, "som trods gode materielle forsyninger ikke kunne finde ind i fællesskab og venskab med andre, de ensomme, de tilpasningsvanskelige" (Krabbe 1959, 123). ${ }^{49}$

Den senere biskop over Københavns Stift, W. Westergaard-Madsen, ytrede meget kontant, at "Den moderne velfærdsstat ... må vi anse for en Guds ordning for vort folk" ${ }^{50}$ Han var dog også kritisk og frygtede "upersonlighedens risiko", der måtte modvirkes ved forkyndelsens fastholdelse af den enkelte på det personlige ansvar for næsten. Det kunne ikke bare placeres i velfærdsstaten. ${ }^{51}$ Det frivillige arbejde "er en forkyndelse i handling af det evangeliske budskab, at staten er Guds ordning ikke for magtens skyld, men til tjeneste for næsten (Madsen 1956a, 27-28). Frivilligheden måtte ses som sam-

46. J.D. Christensen, "Humanisme - et overgangsstadium, Indre Missions Tidende 105, 31 (1958), 391.

47. Tange Jensen, "Diakonien på dagsordenen”, Dansk Kirkeliv 35 (1958), 108-15, 111.

48. Jens Nørgaard, “Diakoni i en velfærdsstat”, Dansk Kirkeliv 39 (1962), 54-60, 58.

49. Otto Krabbe, “Forgår vi af velfærd?”, Presteforeningens Blad 49 (1959), 120-26. Krabbe så velfærdsstaten alene som en "pengefordelingsaffære" (121). Som sådan var det en neutral institution, men den åbnede for udvikling af andre sider af det menneskelige liv.

50. W. Westergaard Madsen, "Frivillighedens betydning i den moderne stat", Det københavnske Kirkefonds Årbog 1955-56, (1956a), 25-31, 25.

51. W. Westergaard Madsen, "Velfærdsstaten som kristeligt problem", De samvirkende Menighedsplejers Årsberetning 1955-56, (1956b), 8-20, 17, 20. Se også W. Westergaard Madsen, "Velfærdsstaten har brug for den kristne tjenende kirke", Kristeligt Dagblad den 18. oktober 1956. Han erklærede, at udviklingen var løbet fra to-regimentelæren, fordi staten havde gjort sig fri af sin oprindelse i en grad, der lå uden for Luthers forestillingsverden (1956a, 27). Han lagde sig i sin vurdering af diakonien tæt på Lambeth-resolutionerne. 
fundets samvittighed ${ }^{52}$ og spejle, "at vi mennesker kommer hinanden ved, at de andres nød angår mig" (Madsen 1956a, 29). Frivilligheden medvirkede til, "at vort menneskelige fællesskab bliver et ægte fællesskab, hvor vi mennesker kommer hinanden ved" (Madsen 1956a, 30). Samtidig advarede han mod risikoen for bureaukratisering og svækkelse af den kirkelige diakoni. Han erkendte, at man måtte være på vagt overfor totalitære tendenser, men fandt Berggravs indhold for kategorisk (Madsen 1956b: 15).

Der var dog også dem i kirkefolket, der tog positivt imod velfærdsstaten og ikke så den som en trussel mod den personlige frihed ${ }^{53}$ eller en svækkelse af den enkeltes etiske holdning. Velfærdsstaten måtte ikke undsiges - og da slet ikke i kristendommens navn. ${ }^{54}$

\section{Sammenfatning}

For Berggrav gav to-regimentelæren kun mening, hvis staten var en retsstat og et organ for alles samvirke. Velfærdsstaten var for ham en sekulariseret, materialistisk livssynsstat på vej mod at blive en omnipotent, al-faderlig og dæmoniseret stat, som satte sig selv på Guds plads. Derfor brød den med to-regimentelærens grundlæggende forudsætning, at Gud var ansvarlig for begge regimenter. I Berggravs optik kunne næstekærlighed kun trives i de livsgrupper, hvor ansvarligheden og omsorgen var forankret. Institutionaliseret i en velfærdsstat blev næstekærligheden perverteret.

Også Temple ville en retsstat som et organ for fællesskabet og så lydighedspligten mere rettet mod fællesskabet end mod staten. Også han frygtede den omnipotente magtstat, men var omvendt mere tilbøjelig til at se velfærdsstaten som retsstat, ligesom han betonede, at to-regimentelæren måtte tolkes anderledes, når den enkelte borger $\mathrm{i}$ et demokrati var aktiv i begge regimenter. Temple og andre anglikanere var mere tilbøjelige til at fortolke øvrighedens opgave videre end Luther. Det handlede ikke kun om at beskytte den enkelte, men også om at sikre sådanne vilkår, at fristelsen til ikke at tage behørigt

52. "Både i mund og skrift og ved sin blotte eksistens må det frivillige arbejde øve en kritisk bedømmelse af det offentlige arbejde, påpege mangler og eftervise notoriske fejl, og det må være et demokratisk samfunds styrke at kunne høre på og lære af sådan kritik" (Madsen 1956a, 30).

53. Torben Jørgensen, “Tryghed i velfærdsstaten”, Sønderjyden den 16. marts 1956.

54. Carl Trock, "Kristendom og velfærdsstat", Kristeligt Dagblad den 4. februar 1959. 
hensyn til sin næste blev imødegået ved velfærdsstatslige initiativer "kærlighed på afstand", som Vidler formulerede det.

Det fælles var frygten for, at velfærdsstaten ville underminere det frivillige arbejde, diakonien, familierne, den personlige frihed og ansvarlighed, de personlighedsprægende aktiviteter etc., som hidtil havde været det åndelige regimentes prærogativ, ligesom man var fælles om det syn, at staten under alle omstændigheder skulle handle i respekt for Guds moralske lov. Det var også en fælles opfattelse, at kirken skulle optræde som modvægt til statens naturlige tendens mod totalitarisme og vedvarende holde de statslige gerninger op imod Guds ord.

Staten var til for borgernes skyld, ikke borgerne for statens, skrev Temple, mens det hos Berggrav lød, at staten ikke ville menneskeliggøres, mens menneskene skulle statsliggøres.

Berggrav øvede stor indflydelse på de danske kirkefolk, der var skeptiske overfor velfærdsstaten; men som i Norge og England lød der også andre røster. Kirkefolkets modtagelse af velfærdsstaten var lige så tvetydig som den øvrige befolknings. Det sætter et lille spørgsmålstegn ved tanken om, at velfærdsstaten skulle være en frugt af en mangeårig luthersk forkyndelse. 